\title{
Contamination of Green Bay water with lead and cadmium by a 37-m long, 2-m draft research vessel
}

\author{
Ronald Rossmann* and James A. Barres \\ Center for Great Lakes and Aquatic Sciences, The University of Michigan, Ann Arbor, MI \\ 48109, USA
}

\begin{abstract}
During late April 1989, Green Bay, Lake Michigan water was sampled for dissolved concentrations of lead and cadmium. Samples used to document horizontal contamination of the water by a research vessel were collected using a rubber boat rowed $2,50,100$, and $200 \mathrm{~m}$ upwind of the anchored mother ship. Samples used to document vertical contamination of the water column by the research vessel were collected from the vessel at water depths of $0.2,2$, 5,10 , and $20 \mathrm{~m}$. Both lead and cadmium blanks were $<0.5 \mathrm{ng} / 1$ and below their limits of detection at the $95 \%$ level of confidence of 3.5 and $0.98 \mathrm{ng} / \mathrm{l}$, respectively. Concentrations of lead in the horizontal direction varied between $3.5 \mathrm{ng} / \mathrm{l}$ at $200 \mathrm{~m}$ from the ship and $7.7 \mathrm{ng} / \mathrm{l}$ at $2 \mathrm{~m}$ from the ship. Cadmium concentrations varied from $2.8 \mathrm{ng} / 1$ at $2 \mathrm{~m}$ from the ship to $1.5 \mathrm{ng} / 1$ at $200 \mathrm{~m}$ from the ship. Lead concentrations in the vertical direction varied between $8.4 \mathrm{ng} / 1$ at a depth of $0.2 \mathrm{~m}$ and $3.3 \mathrm{ng} / 1$ at $5 \mathrm{~m}$. Cadmium concentrations ranged between 4.5 $\mathrm{ng} / 1$ at $2 \mathrm{~m}$ and $2.2 \mathrm{ng} / \mathrm{l}$ at $20 \mathrm{~m}$. The vertical studies were inconclusive and appeared to be influenced by resuspension of bottom sediments. Uncontaminated samples can be collected as close as $100 \mathrm{~m}$ to the research vessel.
\end{abstract}

Key words: lead; cadmium; sample; contamination

\section{INTRODUCTION}

In late April of 1989, water samples were collected for the purpose of documenting their contamination with lead and cadmium by the hull of the mother ship. The study was designed to quantify contamination levels at varying horizontal and vertical distances from the hull of the ship, to confirm the adequacy of currently accepted oceanographic sampling protocols, and to determine whether the use of lesser horizontal and vertical distances from the ship's hull were possible without sample contamination.

*Present address: United States Environmental Protection Agency, Large Lakes Research Station, 9311 Groh Road, Grosse Ile, MI 48138, USA.

0048-9697/92/\$05.00 C 1992 Elsevier Science Publishers B.V. All rights reserved 


\section{EXPERIMENTAL}

\section{Bottle preparation}

Polyethylene bottles with polypropylene caps (new bottles or bottles which have been used since 1969 only for the storage of Great Lakes trace element water samples) were rigorously cleaned utilizing a modification of the procedure described by Bruland et al. (1979). Outside the clean room, bottles were rinsed with acetone, washed in detergent (Alconox ${ }^{\circledR}$ ), rinsed with hot tap water, and triple-rinsed with Millipore Milli-RO ${ }^{\circledR}$ water (MRW). Each bottle was then filled with $3 \mathrm{M}$ reagent grade hydrochloric acid, soaked at $80^{\circ} \mathrm{C}$ for $6 \mathrm{~h}$, triple rinsed with quartz-distilled Milli-RO ${ }^{\circledR}$ water (QDW), soaked in $0.5 \mathrm{M}$ reagent grade nitric acid for $72 \mathrm{~h}$, and triple rinsed with QDW. In the clean room, the bottles were triple rinsed with QDW passed through a Corning ${ }^{\circledR}$ mixed bed ultra-pure deionizing column (QDDW), soaked in $0.5 \mathrm{M}$ Seastar Chemicals ${ }^{\circledR}$ double distilled nitric acid for at least 7 days, and triple rinsed with QDDW. The bottles were numbered sequentially and weighed. To each bottle $2 \mathrm{ml} / 1$ of concentrated Seastar Chemicals ${ }^{\circledR}$ double distilled nitric acid were added. The bottles were then individually sealed in inner and outer polyethylene bags. Groups of 12 bottles were then sealed within inner and outer larger polyethylene bags and removed from the clean room. Prior to placing the bags within a portable clean room, the outer bag was stripped off.

\section{Filter preparation}

Millipore Fluoropore ${ }^{\circledR}$ filters having a $500 \mathrm{~nm}$ pore size were triple-rinsed with and then soaked in reagent grade ethyl alcohol (190 proof) for $24 \mathrm{~h}$ in a pre-cleaned polyethylene bottle. The 24 -h soak was repeated two more times. The filters were then stored in reagent grade ethyl alcohol in the bottles in which they were cleaned. Groups of bottles were then packaged as described previously. Past work has demonstrated that this is an effective way to clean these filters (Rossmann, 1982, 1984, 1986; Rossmann and Barres, 1987, 1988). An organic wetting agent was necessary to render these filters functional for inorganic solutions.

\section{Vial preparation}

Polyethylene vials for storage of filters and their trapped particulates were prepared in a manner similar to that for the polyethylene bottles. They were packaged as described above. 


\section{Equipment preparation}

All sampling and filtration equipment subject to contact by water samples was cleaned in the same manner as the polyethylene bottles. Once cleaned, all the equipment was sealed in polyethylene bags following the protocol described above.

\section{Collection}

\section{Horizontal}

Using an inflatable rubber boat, samples were collected at distances of 2 , 50,100 , and $200 \mathrm{~m}$ from the mother ship. The sampling was done by rowing upwind of the anchored mother ship and hand collecting lake water directly into precleaned sampler bottles. Polyethylene gloves were worn during collection. Collection depth was $0.2 \mathrm{~m}$, following the procedures described by Berman and Yeats (1985). All samples were filtered in a clean room aboard ship and preserved at a $\mathrm{pH}<2$ with ultra-pure, double-distilled nitric acid.

\section{Vertical}

Samples were collected from depths of $0.2,2,5,10$, and $25 \mathrm{~m}$ using a metal-free sampler previously used by the authors and Teflon ${ }^{\circledR}$-coated, metal-free General Oceanics GO-FLO ${ }^{\circledR}$ samplers, attached to Kevlar $^{\circledR}$ line, triggered with a Teflon ${ }^{\circledR}$-coated messenger, and weighted with a Teflon ${ }^{-}$-coated weight (Berman and Yeats, 1985). The hydrostatic release mechanism on the General Oceanics GO-FLO ${ }^{\circledR}$ samplers precluded their use for depths of $10 \mathrm{~m}$ or less. Triggering of a GO-FLO ${ }^{\circledR}$ sampler's hydrostatic release mechanism at $10 \mathrm{~m}$ and raising it to sample depths of $10 \mathrm{~m}$ or less was considered unacceptable because of possible contamination of the GO$\mathrm{FLO}^{\circledR}$ sampler by deeper water with potentially elevated metal concentrations due to either resuspension of sediments or the presence of a nepheloid layer. Samples from depths of $10 \mathrm{~m}$ or less were collected with a metal-free sampler designed to go through the surface micro-layer closed and to be rinsed at collection depth with ambient water (Rossmann and Barres, 1988).

\section{Sample preparation}

\section{Filtration}

Immediately after collection, samples were filtered in a clean room aboard the ship. Filtration was through Teflon ${ }^{\circledR}$ filters having a pore size of $500 \mathrm{~nm}$. The filtration system was the same as that previously used by the authors 
(Rossmann and Barres, 1988). The filtration equipment consisted of an approximately $9.5-\mathrm{cm}$ diameter and a $250-\mathrm{ml}$ capacity polypropylene Buchner funnel. The funnel was fitted with a pliable plastic wrap to form a seal with a hole drilled in the top of a polycarbonate-polypropylene vacuum desiccator.

Each sample was filtered through the funnel with its Teflon ${ }^{\circledR}$ filter into a prepared sample bottle, containing the preservative, housed within the vacuum desiccator. Vacuum was obtained with an oilless vacuum pump. During filtration, $250 \mathrm{ml}$ of distilled-deionized water was filtered and discarded, a sample storage bottle was placed inside the desiccator, and 1 liter of sample or field blank was filtered. The filled storage bottles were then sealed individually in polyethylene bags for transport to the laboratory.

\section{Concentration of samples prior to analysis}

Filtered water samples were freeze-dried to concentrate metal concentrations 50 -fold. Samples to be freeze-dried were always handled in a clean room except during the actual freeze-drying. Samples were placed into precleaned, preweighed polyethylene bottles, weighed, and sealed in polyethylene bags. The bags were then removed from the clean room and placed in a freezer. Once frozen, the outer plastic bag was removed and the samples were returned to the clean room where each bottle's cap was loosened. The bottles were then placed in freeze-drying flasks. The flasks were sealed, removed from the clean room, and placed on an already evacuated freeze-dryer. Once freeze-drying was complete, the flasks were sealed and removed from the freeze-dryer. After rinsing, the flasks were returned to the clean room where they were opened, and the polyethylene bottles were removed. To each freeze-dried sample, $2 \mathrm{ml}$ of QDDW and $5 \mu \mathrm{l}$ of concentrated Seastar Chemicals ${ }^{\circledR}$ nitric acid were added. Again the bottles were sealed, packaged, removed from the clean room, and placed in a bottle rotator on their sides to dissolve the freeze-dried sample. They were rotated for $12 \mathrm{~h}$ before being rinsed and returned to the clean room. In the clean room each bottle was rinsed with QDDW and allowed to stand upright for a minimum of $12 \mathrm{~h}$. At this point the sample was ready for analysis.

Previous work has demonstrated that metals are not lost during freezedrying (Rossmann, 1982). For the current work, $100 \mathrm{ml}$ of QDW water was spiked with lead and cadmium to yield concentrations of $20 \mathrm{ng} / 1$ lead and 2 $\mathrm{ng} / \mathrm{l}$ cadmium. These were freeze-dried using the same procedures as for the samples. Spike recoveries for lead and cadmium were $95 \%$ and $105 \%$, respectively (Table 1).

\section{Sample analyses}

Samples were analyzed for cadmium and lead by flameless atomic absorp- 
TABLE 1

Spike recoveries for freeze-dried samples analyzed for lead and cadmium

\begin{tabular}{lllllc}
\hline Element & $\begin{array}{l}\text { Number of } \\
\text { replicates }\end{array}$ & $\begin{array}{l}\text { Measured } \\
\text { concentration } \\
\text { (ng/l) }\end{array}$ & $\begin{array}{l}\text { Measured } \\
\text { S.D. }\end{array}$ & $\begin{array}{l}\text { Amount of } \\
\text { spike } \\
\text { (ng/l) }\end{array}$ & $\begin{array}{l}\text { Percent } \\
\text { recovery }\end{array}$ \\
\hline $\mathrm{Pb}$ & 4 & 19.0 & 0.33 & 20 & 95 \\
$\mathrm{Cd}$ & 4 & 2.1 & 0.096 & 2 & 105 \\
\hline
\end{tabular}

tion spectrophotometry techniques using a graphite furnace (Perkin-Elmer, 1977; Perkin-Elmer, 1982). Calibration was with standard curves for all analyses. The method of standard additions was used for all lead analyses of samples. Manufacturer's recommended instrument settings were followed (Perkin-Elmer, 1982).

Duplicate samples were analyzed for lead and cadmium using both the methods of standard additions and of standard curve for calibration. Cadmium results were virtually identical for the two methods. Prior to analysis for cadmium, freeze-dried blanks were not diluted, and freeze-dried samples were diluted 11-fold to yield concentrations falling within the linear response range of the instrument.

Lead results for freeze-dried samples did not compare favorably for the two methods of analysis, where as results for the field blanks compared somewhat favorably. Standard curve results for the samples were lower than those based on the method of standard additions. It appears that sample handling during standard addition contaminated the samples. Some results for both methods compared well, while others for the method of standard additions were always higher than those using standard curves for calibration.

\section{RESULTS}

Field blanks were analyzed for the purpose of determining both the amount of blank correction to be applied to the sample results as well as the limit of detection. In this case, the limits of detection are the lead and cadmium concentrations below which a sample cannot be said to differ from the field blanks at the $95 \%$ level of confidence. The limit of detection is equal to twice the criterion of detection. The criterion of detection is equal to the S.D. of the field blanks times a proper constant for the number of cases taken from standard statistical tables (Table 2). Thus no blank correction was ap- 
TABLE 2

Machine, criteria, and limit of detection for Green Bay filtered water samples. The criteria at the $95 \%$ level of confidence and the limit of detection at the $95 \%$ level of confidence are based upon the S.D. of the field blanks. The machine limit of detection is twice the error associated with either the standard curve or the regression line for standard addition. Limits are based upon 50 -fold concentrated blanks and samples

\begin{tabular}{llll}
\hline Element & Description & $\begin{array}{l}\text { Blanks } \\
(\mathrm{ng} / \mathrm{l})\end{array}$ & $\begin{array}{l}\text { Samples } \\
(\mathrm{ng} / \mathrm{l})\end{array}$ \\
\hline $\mathrm{Pb}$ & Machine & 1.0 & 1.0 \\
$\mathrm{Cd}$ & Machine & 0.025 & 0.10 \\
$\mathrm{~Pb}$ & Criteria at $95 \%$ level of confidence & 1.8 & 1.8 \\
$\mathrm{Cd}$ & Criteria at $95 \%$ level of confidence & 0.49 & 0.49 \\
$\mathrm{~Pb}$ & Limit at $95 \%$ level of confidence & 3.5 & 3.5 \\
$\mathrm{Cd}$ & Limit at $95 \%$ level of confidence & 0.98 & 0.98 \\
\hline
\end{tabular}

\section{TABLE 3}

Results for analyses of field blanks for lead and cadmium

\begin{tabular}{llllll}
\hline Element & $\begin{array}{l}\text { Number of } \\
\text { replicates }\end{array}$ & $\begin{array}{l}\text { Minimum } \\
(\mathrm{ng} / 1)\end{array}$ & $\begin{array}{l}\text { Maximum } \\
(\mathrm{ng} / \mathrm{l})\end{array}$ & $\begin{array}{l}\text { Mean } \\
(\mathrm{ng} / \mathrm{l})\end{array}$ & $\begin{array}{l}\text { Standard } \\
\text { deviation }\end{array}$ \\
\hline $\mathrm{Pb}$ & 17 & -1.2 & 1.6 & -0.29 & 0.83 \\
$\mathrm{Cd}$ & 15 & 0.025 & 0.80 & 0.35 & 0.23 \\
\hline
\end{tabular}

\section{TABLE 4}

Lead concentrations at varying distances from the ship. At a distance of $200 \mathrm{~m}$ from the mother ship and a water depth of $14 \mathrm{~m}$ (mid-depth of water column), the concentration of lead was $4.6 \mathrm{ng} / 1$

\begin{tabular}{rlllll}
\hline $\begin{array}{l}\text { Distance } \\
\text { from ship } \\
(\mathrm{m})\end{array}$ & $\begin{array}{l}\text { Number of } \\
\text { replicates }\end{array}$ & $\begin{array}{l}\text { Minimum } \\
(\mathrm{ng} / \mathrm{l})\end{array}$ & $\begin{array}{l}\text { Maximum } \\
(\mathrm{ng} / \mathrm{l})\end{array}$ & $\begin{array}{l}\text { Mean } \\
(\mathrm{ng} / \mathrm{l})\end{array}$ & $\begin{array}{l}\text { Standard } \\
\text { deviation }\end{array}$ \\
\hline 2 & 3 & 6.2 & 8.9 & 7.7 & 1.4 \\
50 & 3 & 4.1 & 6.6 & 5.2 & 1.3 \\
100 & 3 & 3.5 & 5.9 & 4.3 & 1.3 \\
200 & 3 & 2.8 & 3.9 & 3.5 & 0.62 \\
\hline
\end{tabular}




\section{TABLE 5}

Cadmium concentrations at varying distances from the ship. At a distance of $200 \mathrm{~m}$ from the mother ship and a water depth of $14 \mathrm{~m}$ (mid-depth of water column), the concentration of cadmium was $4.0 \mathrm{ng} / 1$

\begin{tabular}{llllll}
\hline $\begin{array}{l}\text { Distance } \\
\text { from ship } \\
\text { (m) }\end{array}$ & $\begin{array}{l}\text { Number of } \\
\text { replicates }\end{array}$ & $\begin{array}{l}\text { Minimum } \\
(\mathrm{ng} / \mathrm{l})\end{array}$ & $\begin{array}{l}\text { Maximum } \\
(\mathrm{ng} / \mathrm{l})\end{array}$ & $\begin{array}{l}\text { Mean } \\
(\mathrm{ng} / \mathrm{l})\end{array}$ & $\begin{array}{l}\text { Standard } \\
\text { deviation }\end{array}$ \\
\hline 2 & 3 & 2.1 & 3.5 & 2.8 & 0.72 \\
50 & 3 & 1.2 & 2.0 & 1.5 & 0.40 \\
100 & 3 & 1.9 & 2.2 & 2.1 & 0.21 \\
200 & 3 & 1.3 & 1.7 & 1.5 & 0.22 \\
\hline
\end{tabular}

plied. Machine limit of detection is the concentration above which an element could be measured for the instrument used for analysis. It is equal to twice the error associated with the standard curve or the standard additions regression line. All sample results for lead and cadmium were above the limit of detection. For both lead and cadmium, mean blank concentrations were below their respective limits of detection (Table 3).

Concentrations of lead in the horizontal direction varied between $3.5 \mathrm{ng} / \mathrm{l}$ at a distance of $200 \mathrm{~m}$ from the ship and $7.7 \mathrm{ng} / \mathrm{l}$ at $2 \mathrm{~m}$ from the ship (Table 4). Cadmium concentrations varied from $2.8 \mathrm{ng} / 1$ at $2 \mathrm{~m}$ from the ship to 1.5 $\mathrm{ng} / \mathrm{l}$ at $200 \mathrm{~m}$ from the ship (Table 5). Lead concentrations in the vertical

\section{TABLE 6}

Lead concentrations at varying water depths adjacent to the ship. At a distance of $200 \mathrm{~m}$ from the mother ship and a water depth of $14 \mathrm{~m}$ (mid-depth of water column), the concentration of lead was $4.9 \mathrm{ng} / 1$

\begin{tabular}{llllll}
\hline $\begin{array}{l}\text { Water depth } \\
(\mathrm{m})\end{array}$ & $\begin{array}{l}\text { Number of } \\
\text { replicates }\end{array}$ & $\begin{array}{l}\text { Minimum } \\
(\mathrm{ng} / \mathrm{l})\end{array}$ & $\begin{array}{l}\text { Maximum } \\
(\mathrm{ng} / \mathrm{l})\end{array}$ & $\begin{array}{l}\text { Mean } \\
(\mathrm{ng} / \mathrm{l})\end{array}$ & $\begin{array}{l}\text { Standard } \\
\text { deviation }\end{array}$ \\
\hline 0.2 & 3 & 7.3 & 9.7 & 8.4 & 1.2 \\
2 & 3 & 2.4 & 3.7 & 3.3 & 0.76 \\
5 & 3 & 3.9 & 5.6 & 4.6 & 0.84 \\
10 & 3 & 6.6 & 7.4 & 7.0 & 0.43 \\
20 & 3 & 5.7 & 8.4 & 6.9 & 1.4 \\
\hline
\end{tabular}


TABLE 7

Cadmium concentrations at varying water depths adjacent to the ship. At a distance of 200 $\mathrm{m}$ from the mother ship and a water depth of $14 \mathrm{~m}$ (mid-depth of water column), the concentration of cadmium was $4.0 \mathrm{ng} / 1$

\begin{tabular}{rlllll}
\hline $\begin{array}{l}\text { Water depth } \\
(\mathrm{m})\end{array}$ & $\begin{array}{l}\text { Number of } \\
\text { replicates }\end{array}$ & $\begin{array}{l}\text { Minimum } \\
(\mathrm{ng} / \mathrm{l})\end{array}$ & $\begin{array}{l}\text { Maximum } \\
(\mathrm{ng} / \mathrm{l})\end{array}$ & $\begin{array}{l}\text { Mean } \\
(\mathrm{ng} / \mathrm{l})\end{array}$ & $\begin{array}{l}\text { Standard } \\
\text { deviation }\end{array}$ \\
\hline 0.2 & 3 & 1.6 & 3.1 & 2.5 & 0.78 \\
2.0 & 3 & 2.7 & 6.6 & 4.5 & 2.0 \\
5.0 & 3 & 2.8 & 5.6 & 4.2 & 1.4 \\
10.0 & 3 & 2.2 & 3.5 & 2.6 & 0.73 \\
20.0 & 3 & 1.8 & 2.6 & 2.2 & 0.38 \\
\hline
\end{tabular}

direction varied between $8.4 \mathrm{ng} / 1$ at a depth of $0.2 \mathrm{~m}$ and $3.3 \mathrm{ng} / 1$ at $5 \mathrm{~m}$ (Table 6). Cadmium concentrations ranged between $4.5 \mathrm{ng} / \mathrm{l}$ at $2 \mathrm{~m}$ and 2.2 $\mathrm{ng} / 1$ at $20 \mathrm{~m}$ (Table 7).

\section{DISCUSSION}

Those who collect water samples for trace element analyses are well aware of the contaminating impact of the mother ship upon the water column adjacent to the ship. Current accepted methodology calls for near-surface water samples to be collected $200 \mathrm{~m}$ upwind of the ship using a rubber raft that is rowed to the site (Bruland et al., 1979; Schaule and Patterson, 1981; Danielsson et al., 1985). If weather or sea conditions preclude the use of a rubber raft, or if samples are needed from deeper in the water column, sampling can be accomplished from the mother ship at depths of $20 \mathrm{~m}$ or greater (Danielsson et al., 1985). For the collection of Green Bay water samples, the $200 \mathrm{~m}$ recommended distance from the mother ship could routinely result in inappropriate risks being taken by those collecting the samples, especially at night during heavy ship traffic. Likewise a collection depth of $20 \mathrm{~m}$ or greater below the hull of the ship would lead to the loss of sampling opportunities because of the very shallow nature of the bay and the requirement that samples be collected from mid-depth of the water column. Results of this study support our contention that samples can be collected at locations less than $200 \mathrm{~m}$ from the mother ship and at depths less than $20 \mathrm{~m}$ below the ship's hull.

Dissolved lead concentrations in samples collected within $2 \mathrm{~m}$ of the ship were nearly $4-5 \mathrm{ng} / 1$ greater than those in samples collected at distances of 
$100 \mathrm{~m}$ or more away from the ship (Table 4). Because results for samples collected at 100 and $200 \mathrm{~m}$ are similar, the elevated concentration $2 \mathrm{~m}$ from the ship is most likely not a natural horizontal variation, but it is ship contamination of water adjacent to the ship. These results lead to the conclusion that sampling can occur as close as $100 \mathrm{~m}$ to the mother ship.

The variations of dissolved cadmium concentrations with increasing distance from the mother ship are less conclusive than those for lead because of the high limit of detection and high S.D.s for replicate analyses relative to the measured concentrations (Tables 2 and 5). However, the highest mean concentration occurs at $2 \mathrm{~m}$ from the ship's hull, suggesting that sample collection should occur at $50 \mathrm{~m}$ or more away from the ship (Table 5).

The vertical studies were inconclusive and appeared to be influenced by natural vertical variability of metal concentrations. Resuspension of bottom sediments may be responsible for the observed vertical variation in lead and cadmium concentrations. The water depth was only $28 \mathrm{~m}$. Lead concentrations were lowest $2 \mathrm{~m}$ below the surface and reached a maximum at surface and at $10 \mathrm{~m}$ water depth (Table 6). Cadmium concentrations were lowest near the surface and deeper within the water column (Table 7). For cadmium, the same restrictions apply to vertical results as horizontal results.

For cadmium concentrations, it is not possible to discern the contamination of the water column by the ship from elevated concentrations due to natural vertical variability. The ship does appear to contaminate the surface water $(0.2 \mathrm{~m})$. Comparison of horizontal study and vertical study results with those for a sample collected for the Green Bay monitoring program provides insight into the true metal concentration at varying water depths. The monitoring sample collected at $14 \mathrm{~m}$ water depth and a distance of $200 \mathrm{~m}$ from the mother ship contained dissolved lead and cadmium concentrations of 4.9 and $4.0 \mathrm{ng} / 1$, respectively. This sample was apparently collected at a depth which sampled the nepheloid layer containing resuspended sediments. The lead concentration compares very favorably with the $4.6 \mathrm{ng} / 1$ obtained for the 5-m sample collected from the mother ship. Samples collected at depths of 2 and $5 \mathrm{~m}$ using the ship (3.3-4.6 ng/l) compare favorably with those collected from a depth of $0.2 \mathrm{~m}$ at distances of 50,100 , and $200 \mathrm{~m}$ from the mother ship (3.5-5.2 ng/l). Results compared favourably the sample collected at a depth of $0.2 \mathrm{~m}$ at a distance of $2 \mathrm{~m}$ from the hull of the mother ship between the horizontal study $(7.7 \mathrm{ng} / \mathrm{l})$ and the vertical study $(8.4 \mathrm{ng} / \mathrm{l})$. The cadmium concentration in the samples collected at a depth of $14 \mathrm{~m}$ and a distance of $200 \mathrm{~m}$ from the mother ship is higher than any of those for samples collected from the ship.

Thus when lead concentrations are expected to be $5 \mathrm{ng} / \mathrm{l}$ or greater, surface water samples that are uncontaminated with lead can be collected as close as $50 \mathrm{~m}$ to the research vessel. In cases where the samples must be collected 
from the mother ship, samples can be collected from water depths as shallow as $2 \mathrm{~m}$. When cadmium concentrations are 1-7 $\mathrm{ng} / 1$, samples uncontaminated with cadmium can be collected from the mother ship at any depth. These conclusions apply only to the sampling of waters having lead and cadmium concentrations similar to those reported here and only to anchored research vessels up to $37 \mathrm{~m}$ in length with a maximum draft of $2 \mathrm{~m}$. For the entire Green Bay project, our protocol called for collection of samples 100 $m$ away from the mother ship. When the rubber boat could not be used, sampling depth had to be $5 \mathrm{~m}$ or greater.

\section{ACKNOWLEDGEMENTS}

We wish to thank the captain and crew of the R/V Roger R. Simons for their assistance with sample collection. A special thanks to Donna Francis, Steven Riggs, and Mark Smith for assistance with preparation of materials and analysis of the samples. Thanks to the United States Environmental Protection Agency Large Lakes Research Station and Great Lakes National Program Office staff for their support. Support provided by United States Environmental Protection Agency Grant CR-815270-01. Contribution to the Center for Great Lakes and Aquatic Sciences, The University of Michigan.

\section{REFERENCES}

Berman, S.S. and P.A. Yeats, 1985. Sampling of seawater for trace metals. Crit. Rev. Anal. Chem., 16: 1-14.

Bruland, K.W., R.P. Franks, G.A. Knauer and J.H. Martin, 1979. Sampling and analytical methods for the determination of copper, cadmium, zinc, and nickel at the nanogram per liter level in sea water. Anal. Chim. Acta, 105: 233-245.

Danielsson, L., B. Magnusson and S. Westerlund, 1985. Cadmium, copper, iron, nickel and zinc in the north-east Atlantic Ocean. Mar. Chem., 17: 23-41.

Perkin-Elmer, 1977. Analytical methods for atomic absorption spectroscopy using the HGA graphite furnace. Perkin-Elmer Corporation, Norwalk, CT.

Perkin-Elmer. 1982. Analytical methods for atomic absorption spectrophotometry. PerkinElmer Corporation, Norwalk, CT.

Rossmann, R., 1982. Trace metal chemistry of the waters of Lake Huron. Publication 21 of Great Lakes Research Division, The University of Michigan.

Rossmann, R., 1984. Trace metal concentration in the offshore waters of Lakes Erie and Michigan. Spec. Rept. No. 108 of Great Lakes Research Division, The University of Michigan.

Rossmann, R., 1986. Trace metal concentrations in the offshore waters and sediments of Lake Superior. Spec. Rept. No. 121 of Great Lakes Research Division, The University of Michigan.

Rossmann, R. and J. Barres, 1987. Data report on trace elements in the waters of Lake Ontario during August 1985. Final data report to Great Lakes National Program Office, United States Environmental Protection Agency, Chicago, Illinois. 
Rossmann, R. and J. Barres, 1988. Trace element concentrations in near-surface waters of the Great Lakes and methods of collection, storage, and analysis. J. Great Lakes Res., 14: 188-204

Schaule, B.K. and C.C. Patterson, 1981. Lead concentrations in the northeast Pacific: evidence for global anthropogenic perturbations. Earth Planet. Sci. Lett., 54: 97-116. 